\title{
Culture Viability, TBA Values and Sensorial Attributes of Yoghurt Fortified with Microencapsulated Whey Protein-Chelated Iron
}

\author{
A. Elango ${ }^{1^{*}}$, R. Subash ${ }^{2}$, K.A. Doraisamy ${ }^{3}$ and N. Karthikeyan ${ }^{4}$ \\ ${ }^{1}$ Department of Veterinary Public Health and Epidemiology, Madras Veterinary College, Tamil \\ Nadu Veterinary and Animal Sciences University, Chennai-600 007, Tamil Nadu, India \\ ${ }^{2}$ Bargur Cattle Research Station, Bargur, Erode, Tamil Nadu, India \\ ${ }^{3}$ Veterinary College and Research Institute, Namakkal-637 002, Tamil Nadu, India \\ ${ }^{4}$ Department of Livestock Products Technology (Dairy Science), Veterinary College and \\ Research Institute, Namakkal-637 002, Tamil Nadu, India \\ *Corresponding author
}

A B S T R A C T

Using dairy foods as a vehicle for supplementing iron seems to be advantage as ironfortified dairy foods have a relatively high iron bioavailability. In this regard, a study was designed to formulate microencapsulated whey protein-chelated iron ( $\mathrm{Fe}-\mathrm{wp}$ ) using ferrous sulphate that could be used to fortify yoghurt and to determine the TBA values and some

Keywords important sensorial attributes of the developed yoghurt. Influence of iron on survival of yoghurt culture, TBA values of yoghurt and sensory properties of yoghurt were tested by

Yoghurt, Iron fortification, Microencapsulation, Culture survival, TBA values, Sensorial attributes.

Article Info

Accepted:

14 September 2017 Available Online:

10 October 2017 control, free iron and encapsulated iron fortification. Statistically no significant $(\mathrm{P}>0.05)$ difference was noticed in count of Lactobacillus delbrueckii ssp. bulgaricus and Streptococcus salivarius ssp. thermophilus between control and different iron fortified yoghurt treatments on $0,7,14$ and 21 days. During storage period, the count of Lactobacillus delbrueckii ssp. bulgaricus and Streptococcus salivarius ssp. thermophilus significantly $(\mathrm{P}<0.05)$ decreased both in control and as well as in iron fortified yoghurt and thus the fortified iron did not affect the viability of yoghurt bacteria. The TBA values of unencapsulated iron fortified yoghurt was significantly $(\mathrm{P}<0.05)$ higher when compared to control and encapsulated iron fortified yoghurt. Significant $(\mathrm{P}<0.05)$ difference was observed in astringent and oxidized flavour at $0,7,14$ and $21^{\text {st }}$ day of storage between control and different treatments of yoghurt. In addition, significant $(\mathrm{P}<0.05)$ difference was observed in overall preference at $0,7,14$ and $21^{\text {st }}$ day of storage between control and different treatments of yoghurt and between different storage periods. It is demonstrated that microencapsulated whey protein chelated iron can be added up to a level of $80 \mathrm{mg}$ per litre of yoghurt without altering the accepted appearance and sensorial attributes.

\section{Introduction}

Iron deficiency leads to anemia, altered mental development, decreased immunity, impaired cognitive scores. Iron deficiency anaemia is still the most prevalent nutritional problem, which affects $30 \%$ of the world's population. In India, 79\% of children between 6 and 35 months and women between 15 and 49 years of age are anaemic; inadequate intake of iron and consumption of foods low in bioavailable iron are identified as the major 
cause of iron deficiency anaemia (Tripathi and Platel, 2011)

This deficiency causes more than half the maternal deaths in the world (Juneja et al., 2004). Iron deficiency adversely affects the cognitive performance, behaviour, and physical growth of children, immune status, physical capacity and work performance of all age groups and increases perinatal risks for mothers and neonates (WHO, 2001). Iron deficiency anaemia affects $60 \%$ of Asian women of reproductive age and 40 to $50 \%$ of children enrolled in preschool and primary grades (Joseph, 2000). It is estimated that up to half of all anaemia is caused by dietary iron deficiency. Fortification of daily foods to obtain the recommended daily dietary allowances for iron (10- $15 \mathrm{mg}$ for adults) is one of the most effective solutions (Bender and Bender, 1997). Dairy products are widely consumed, providing high quality proteins, vitamins and minerals except iron. Lack of iron in dairy products decreases the iron density of diets when the proportion of dairy products in the diets increases, so it is logical that fortifying dairy products with iron may increases dietary iron density of the people who consume large amounts of dairy products. Of late, among the dairy products, yoghurt has been gaining widespread consumer acceptance owing to its health giving attributes. It is an excellent source of calcium and protein but as is typical of all dairy products, contains very little iron. Therefore, dairy products are logical vehicles for iron fortification because they have high nutritive values, reach target population and are widely consumed. However, iron fortification is difficult in food processing due to potential oxidized off-flavors, color changes, and metallic flavors, probably as a result of lipid prooxidation of milk fat. Hence, the ideal iron compound for food fortification should be one that supplies highly bioavailable iron, does not affect the nutritional value or sensory properties of the food, should be stable during food processing, and of low cost, in order to be accessible for the whole population (Boccio et al., 1998). The bioavailability of ferrous iron, especially ferrous sulfate, is high because the solubility of ferrous iron is higher than that of ferric iron. Ferrous iron is not very stable in solution and is easily oxidised to the insoluble ferric form and hither to several methods of stabilizing ferrous iron in solution have been investigated and Iron-protein complexes have shown high iron bioavailability similar to $\mathrm{FeSO}_{4}$. Keeping the above technical constraints, the proposed investigation of microencapsulation of whey protein chelated iron and incorporation in the development of fortified yoghurt has been designed in such a way that it will definitely supply highly bioavailability iron with no effect on nutritional value or sensory properties of the yoghurt and will be stable during processing and storage and will be of low cost.

\section{Materials and Methods}

\section{Experimental design}

\section{Microencapsulation of iron by emulsion method}

Whey protein chelated iron (Fe-Wp) was prepared by adding $8 \mathrm{~g}$ of ferrous sulphate into $100 \mathrm{ml}$ of 20 per cent whey protein solution and heating to precipitate the complex. The precipitate was centrifuged at $8000 \mathrm{G}$ for $5 \mathrm{~min}$ : washed once with 0.25 per cent lactic acid solution and twice with deionised water. Microencapsulated whey protein chelated iron (MFe-Wp) was prepared by method of Azzam (2009). One part of FeWp mixed with four parts sodium alginate solution ( 3 per cent). To one part of the mixture $10 \mathrm{ml}$ was then added drop wise to 5 parts of sunflower oil $50 \mathrm{ml}$ containing $0.1 \mathrm{w} / \mathrm{v}$ tween 80 and stirred at $200 \mathrm{rpm}$ by 
magnetic stirrer. Within 10 minutes a turbid emulsion was obtained. Calcium chloride $0.05 \mathrm{M}$ was added quickly to the beaker until the water oil emulsion was broken. Calcium alginate encapsulated beads containing $\mathrm{Fe}$ $\mathrm{Wp}$ were formed within $10 \mathrm{~min}$. The microcapsules were collected by gentle centrifugation ( $350 \mathrm{~g}$ for $10 \mathrm{~min}$ ) and washed with distilled water using the same centrifugation conditions, and stored at $4^{\circ} \mathrm{C}$ until used.

\section{Preparation of plain yoghurt and iron fortified yoghurt}

Plain yoghurt was prepared using fresh milk. Skim milk powder at the rate of 4 per cent $(\mathrm{w} / \mathrm{v})$ and sugar at the rate of 6 per cent $(\mathrm{w} / \mathrm{v})$ were added to it and homogenized at 2500 psi. The contents were mixed well and pasteurized at $85^{\circ} \mathrm{C}$ for 30 minutes, cooled to room temperature and inoculated with 2 per cent of yoghurt cultures containing Lactobacillus delbrueckii ssp. bulgaricus, and Streptococcus salivarius ssp. thermophilus. It was then mixed well and incubated at $42^{\circ} \mathrm{C}$ for 4 to 5 hours and finally stored at $5^{\circ} \mathrm{C}$. In regard to the treatment yoghurt, the encapsulated iron beads / unencapsulated iron were added separately as given in the experimental design in the respective treatments to 1 litre of mix. It was then mixed well and incubated at $42^{\circ} \mathrm{C}$ for 4 to 5 hours and finally stored at 4 to $5^{\circ} \mathrm{C}$.

\section{Preparation of iron fortified yoghurt}

Different lots of iron fortified yoghurt were prepared using fresh milk. Skim milk powder at the rate of 4 per cent $(\mathrm{w} / \mathrm{v})$ and sugar at the rate of 6 per cent $(\mathrm{w} / \mathrm{v})$ were added to it and homogenized at 2500 psi. The contents were mixed well and pasteurized at $85^{\circ} \mathrm{C}$ for 30 minutes, cooled to room temperature and inoculated with 2 per cent of yoghurt cultures containing Lactobacillus delbrueckii ssp. bulgaricus, and Streptococcus salivarius ssp. thermophilus. Then encapsulated iron beads / unencapsulated iron were added separately as per the treatments to 1 litre of mix. It was then mixed well and incubated at $42^{\circ} \mathrm{C}$ for 4 to 5 hours and finally stored at 4 to $5^{\circ} \mathrm{C}$.

The prepared iron fortified yoghurt was subjected to organoleptic evaluation, TBA value and enumeration of count of yoghurt bacteria employing the procedure given by Kim et al.,(2003) and the data obtained in all the experiments were analyzed statistically by applying one way and two way ANOVA (Snedecor and Cochran, 1994).

\section{Results and Discussion}

Thiobarbituric acid values of microencapsulated iron fortified yoghurt (absorbance at $532 \mathrm{~nm}$ )

In regard TBA value, significantly higher values were observed in unencapsulated iron fortified yoghurt (PFSY2), when compared to control and capsulated iron fortified yoghurt (IFY) treatments (Table 1).

The mean $( \pm$ SE) TBA of control and iron fortified yoghurt at $0,7,14$ and 21 days of storage period are shown in Table 1. The TBA values of control and iron fortified yoghurt ranged from $0.0132 \pm 0.02$ to $0.0989 \pm 0.02$. Statistically significant $(\mathrm{P}<0.05)$ difference was noticed in TBA values between control and iron fortified yoghurts. During storage of yoghurt there was significant $(\mathrm{P}<0.05)$ increase in TBA was also observed between control and iron fortified yoghurt.

Effect of iron fortification on viability of Lactobacillus delbrueckii ssp. bulgaricus in yoghurt $\left(\log _{10} \mathrm{cfu} / \mathrm{ml}\right)$

Table 2 shows the mean ( \pm SE) values of count of Lactobacillus delbrueckii ssp. bulgaricus between control and iron fortified 
yoghurt treatments ranged from $9.29 \pm 0.01$ to $7.41 \pm 0.01$ during storage period of $0,7,14$ and 21 days at $5^{\circ} \mathrm{C}$. Statistically no significant ( $P>0.05)$ difference was noticed in count of Lactobacillus delbrueckii ssp. bulgaricus between control and different iron fortified yoghurt (IFY) treatments on day 0. As the storage period advances to 21 days there was significant reduction in the count of Lactobacillus delbrueckii ssp. bulgaricus.

Effect of iron fortification on Streptococcus salivarius ssp. thermophilus viability in yoghurt $\left(\log _{10} \mathrm{cfu} / \mathrm{ml}\right)$

Table 3 shows the mean $( \pm$ SE) values of count of Streptococcus salivarius ssp. thermophilus between control and different IFY treatments ranged from $8.93 \pm 0.02$ to $7.10 \pm 0.01$ during storage period of $0,7,14$ and 21 days at $5^{\circ} \mathrm{C}$. Statistically no significant ( $\mathrm{P}>0.05)$ difference was noticed in count of Streptococcus salivarius ssp. thermophilus between control and IFY treatments.

\section{Effect of iron fortification on bitterness, metallic flavour and astringent flavour in yoghurt}

Table 4 shows the mean $( \pm$ SE) values of bitterness between control and IFY treatments during storage period of $0,7,14$ and 21 days at $5^{\circ} \mathrm{C}$. The bitterness scores ranged from 1.05 \pm 0.17 to $7.40 \pm 0.12$ between control and different IFY up to 21 days of storage at $5^{\circ} \mathrm{C}$. No significant $(\mathrm{P}>0.05)$ difference was noticed between control and IFY treatments at 0 day, whereas significant $(\mathrm{P}<0.05)$ difference was observed at 7,14 and $21^{\text {st }}$ day of storage. Results indicate no significant $(\mathrm{P}>0.05)$ difference between storage periods.

Table 5 shows the mean $( \pm$ SE) values of metallic flavour of control and different IFY treatments during storage period of $0,7,14$ and 21 days at $5^{\circ} \mathrm{C}$. - The metallic flavour scores ranged from $1.04 \pm 0.17$ to $7.49 \pm 0.12$ between control and IFY treatments during 21 days of storage period at $5^{\circ} \mathrm{C}$. No significant $(\mathrm{P}>0.05)$ difference was noticed between control and IFY treatments at 0 day, whereas significant $(\mathrm{P}<0.05)$ difference was observed at 7,14 and $21^{\text {st }}$ day of storage between control and IFY treatments. Results also indicate that no significant $(\mathrm{P}>0.05)$ difference in metallic flavour was observed between storage periods.

Table 6 shows the mean $( \pm$ SE) values of astringent flavour scores between control and IFY treatments during the storage period of 0 , 7,14 and 21 days at $5^{\circ} \mathrm{C}$. The astringent flavour scores ranged from $1.30 \pm 0.06$ to 7.30 \pm 0.15 between control and IFY treatments during 21 days of storage period at $5^{\circ} \mathrm{C}$. Significant $(\mathrm{P}<0.05)$ difference was observed in astringent flavour at $0,7,14$ and $21^{\text {st }}$ day of storage between control and IFY treatments.

\section{Different treatments of yoghurt were designed as detailed below}

\begin{tabular}{|l|c|l|}
\hline PY & - & Control-without addition of iron \\
\hline PFSY1 & - & $20 \mathrm{mg} /$ litre of un-encapsulated ferrous sulphate \\
\hline PFSY2 & - & $40 \mathrm{mg} /$ litre of un-encapsulated ferrous sulphate \\
\hline MFSY1 & - & $20 \mathrm{mg} /$ litre of encapsulated whey protein chelated ferrous sulphate \\
\hline MFSY2 & - & $40 \mathrm{mg} /$ litre of encapsulated whey protein chelated ferrous sulphate \\
\hline MFSY3 & - & $80 \mathrm{mg} /$ litre of encapsulated whey protein chelated ferrous sulphate \\
\hline MFSY4 & - & $100 \mathrm{mg} /$ litre of encapsulated whey protein chelated ferrous sulphate \\
\hline
\end{tabular}


Table.1 Thiobarbituric acid values of microencapsulated iron fortified yoghurt (Absorbance at $532 \mathrm{~nm}$ )

\begin{tabular}{|c|c|c|c|c|}
\hline \multirow{2}{*}{ Treatment } & \multicolumn{4}{|c|}{ Duration } \\
\cline { 2 - 5 } & 0 day & $\mathbf{7 ~ d a y s ~}^{\mathrm{Aa}}$ & $\mathbf{1 4}$ days & $\mathbf{2 1}$ days \\
\hline PY & $0.0132^{\mathrm{Aa}} \pm 0.02$ & $0.0164^{\mathrm{Ba}} \pm 0.03$ & $0.0227^{\mathrm{Ca}} \pm 0.09$ & $0.0346^{\mathrm{Da}} \pm 0.03$ \\
\hline PFSY1 & $0.0133^{\mathrm{Aa}} \pm 0.02$ & $0.0167^{\mathrm{Ba}} \pm 0.03$ & $0.0242^{\mathrm{Ca}} \pm 0.03$ & $0.0350^{\mathrm{Da}} \pm 0.01$ \\
\hline PFSY2 & $0.0135^{\mathrm{Aa}} \pm 0.01$ & $0.0392^{\mathrm{Bb}} \pm 0.02$ & $0.0743^{\mathrm{Ca}} \pm 0.09$ & $0.0989^{\mathrm{Da}} \pm 0.02$ \\
\hline MFSY1 & $0.0132^{\mathrm{Aa}} \pm 0.02$ & $0.0165^{\mathrm{Ba}} \pm 0.03$ & $0.0227^{\mathrm{Ca}} \pm 0.09$ & $0.0345^{\mathrm{Da}} \pm 0.04$ \\
\hline MFSY2 & $0.0132^{\mathrm{Aa}} \pm 0.02$ & $0.0166^{\mathrm{Ba}} \pm 0.04$ & $0.0231^{\mathrm{Ca}} \pm 0.09$ & $0.0347^{\mathrm{Da}} \pm 0.03$ \\
\hline MFSY3 & $0.0133^{\mathrm{Aa}} \pm 0.05$ & $0.0167^{\mathrm{Ba}} \pm 0.03$ & $0.0235^{\mathrm{Ca}} \pm 0.08$ & $0.0348^{\mathrm{Da}} \pm 0.04$ \\
\hline MFSY4 & $0.0135^{\mathrm{Aa}} \pm 0.03$ & $0.0167^{\mathrm{Ba}} \pm 0.06$ & $0.0241^{\mathrm{Ca}} \pm 0.01$ & $0.0348^{\mathrm{Da}} \pm 0.04$ \\
\hline
\end{tabular}

Table.2 Effect of iron fortification on viability of Lactobacillus delbrueckii ssp. Bulgaricus in yoghurt $\left(\log _{10} \mathrm{cfu} / \mathrm{ml}\right)$

\begin{tabular}{|c|c|c|c|c|}
\hline \multirow{2}{*}{ Treatment } & \multicolumn{4}{|c|}{ Duration } \\
\cline { 2 - 5 } & 0 day & $\mathbf{7}$ days & $\mathbf{1 4}$ days & 21 days \\
\hline PY & $9.15^{\mathrm{Aa}} \pm 0.02$ & $8.83^{\mathrm{Ba}} \pm 0.01$ & $8.19^{\mathrm{Ca}} \pm 0.01$ & $7.66^{\mathrm{Da}} \pm 0.01$ \\
\hline PFSY1 & $9.13^{\mathrm{Aa}} \pm 0.01$ & $8.68^{\mathrm{Ba}} \pm 0.01$ & $8.10^{\mathrm{Ca}} \pm 0.01$ & $7.47^{\mathrm{Da}} \pm 0.01$ \\
\hline PFSY2 & $9.07^{\mathrm{Aa}} \pm 0.01$ & $8.62^{\mathrm{Ba}} \pm 0.01$ & $8.16^{\mathrm{Ca}} \pm 0.01$ & $7.41^{\mathrm{Da}} \pm 0.01$ \\
\hline MFSY1 & $9.19^{\mathrm{Aa}} \pm 0.01$ & $8.56^{\mathrm{Ba}} \pm 0.02$ & $8.19^{\mathrm{Ca}} \pm 0.01$ & $7.55^{\mathrm{Da}} \pm 0.01$ \\
\hline MFSY2 & $9.29^{\mathrm{Aa}} \pm 0.01$ & $8.63^{\mathrm{Ba}} \pm 0.01$ & $8.20^{\mathrm{Ca}} \pm 0.01$ & $7.57^{\mathrm{Da}} \pm 0.02$ \\
\hline MFSY3 & $9.20^{\mathrm{Aa}} \pm 0.01$ & $8.95^{\mathrm{Ba}} \pm 0.01$ & $8.29^{\mathrm{Ca}} \pm 0.01$ & $7.71^{\mathrm{Da}} \pm 0.01$ \\
\hline MFSY4 & $9.19^{\mathrm{Aa}} \pm 0.01$ & $8.63^{\mathrm{Ba}} \pm 0.01$ & $8.19^{\mathrm{Ca}} \pm 0.01$ & $7.55^{\mathrm{Da}} \pm 0.01$ \\
\hline
\end{tabular}

Table.3 Effect of iron fortification on Streptococcus salivarius ssp.

Thermophiles viability in yoghurt $\left(\log _{10} \mathrm{cfu} / \mathrm{ml}\right)$

\begin{tabular}{|c|c|c|c|c|}
\hline \multirow{2}{*}{ Treatment } & \multicolumn{4}{|c|}{ Duration } \\
\cline { 2 - 5 } & $\mathbf{0 ~ d a y}$ & $\mathbf{7 ~ d a y s}$ & $\mathbf{1 4}$ days & $\mathbf{2 1}$ days \\
\hline PY & $8.93^{\mathrm{Aa}} \pm 0.02$ & $8.43^{\mathrm{Ba}} \pm 0.01$ & $7.82^{\mathrm{Ca}} \pm 0.01$ & $7.26^{\mathrm{Da}} \pm 0.01$ \\
\hline PFSY1 & $8.73^{\mathrm{Aa}} \pm 0.01$ & $8.11^{\mathrm{Ba}} \pm 0.01$ & $7.680^{\mathrm{Ca}} \pm 0.01$ & $7.17^{\mathrm{Da}} \pm 0.01$ \\
\hline PFSY2 & $8.72^{\mathrm{Aa}} \pm 0.01$ & $8.18^{\mathrm{Ba}} \pm 0.01$ & $7.56^{\mathrm{Ca}} \pm 0.01$ & $7.10^{\mathrm{Da}} \pm 0.01$ \\
\hline MFSY1 & $8.79^{\mathrm{Aa}} \pm 0.01$ & $8.26^{\mathrm{Ba}} \pm 0.02$ & $7.79^{\mathrm{Ca}} \pm 0.01$ & $7.15^{\mathrm{Da}} \pm 0.01$ \\
\hline MFSY2 & $8.83^{\mathrm{Aa}} \pm 0.01$ & $8.13^{\mathrm{Ba}} \pm 0.01$ & $7.60^{\mathrm{Ca}} \pm 0.01$ & $7.22^{\mathrm{Da}} \pm 0.02$ \\
\hline MFSY3 & $8.85^{\mathrm{Aa}} \pm 0.01$ & $8.35^{\mathrm{Ba}} \pm 0.01$ & $7.78^{\mathrm{Ca}} \pm 0.01$ & $7.24^{\mathrm{Da}} \pm 0.01$ \\
\hline MFSY4 & $8.81^{\mathrm{Aa}} \pm 0.01$ & $8.33^{\mathrm{Ba}} \pm 0.01$ & $7.79^{\mathrm{Ca}} \pm 0.01$ & $7.23^{\mathrm{Da}} \pm 0.01$ \\
\hline
\end{tabular}

Table.4 Effect of iron fortification on bitterness in yoghurt

\begin{tabular}{|c|c|c|c|c|}
\hline \multirow{2}{*}{ Treatment } & \multicolumn{5}{|c|}{ Duration } \\
\cline { 2 - 5 } & 0 day & 7 days & 14 days & 21 days \\
\hline PY & $1.05^{\text {Aa }} \pm 0.17$ & $1.10^{\text {Aa }} \pm 0.09$ & $1.15^{\text {Aa }} \pm 0.09$ & $1.17^{\text {Aa }} \pm 0.10$ \\
\hline PFSY1 & $1.23^{\text {Aa }} \pm 0.11$ & $1.46^{\text {Aa }} \pm 0.15$ & $1.50^{\text {Aa }} \pm 0.12$ & $1.63^{\text {Aa }} \pm 0.09$ \\
\hline PFSY2 & $1.60^{\text {Aa }} \pm 0.13$ & $3.80^{\mathrm{Bb}} \pm 0.14$ & $5.20^{\mathrm{Cb}} \pm 0.11$ & $7.40^{\mathrm{Db}} \pm 0.12$ \\
\hline MFSY1 & $1.11^{\mathrm{Aa}} \pm 0.20$ & $1.20^{\mathrm{Aa}} \pm 0.15$ & $1.33^{\mathrm{Aa}} \pm 0.17$ & $1.38^{\mathrm{Aa}} \pm 0.18$ \\
\hline MFSY2 & $1.12^{\mathrm{Aa}} \pm 0.19$ & $1.21^{\mathrm{Aa}} \pm 0.15$ & $1.33^{\mathrm{Aa}} \pm 0.17$ & $1.39^{\mathrm{Aa}} \pm 0.18$ \\
\hline MFSY3 & $1.13^{\mathrm{Aa}} \pm 0.20$ & $1.22^{\mathrm{Aa}} \pm 0.15$ & $1.33^{\mathrm{Aa}} \pm 0.17$ & $1.39^{\mathrm{Aa}} \pm 0.19$ \\
\hline MFSY4 & $1.11^{\mathrm{Aa}} \pm 1.19$ & $1.19^{\mathrm{Aa}} \pm 0.14$ & $1.31^{\mathrm{Aa}} \pm 0.16$ & $1.37^{\mathrm{Aa}} \pm 0.18$ \\
\hline
\end{tabular}


Table.5 Effect of iron fortification on metallic flavour in yoghurt

\begin{tabular}{|c|c|c|c|c|}
\hline \multirow{2}{*}{ Treatment } & \multicolumn{4}{|c|}{ Duration } \\
\cline { 2 - 5 } & 0 day & 7 days & 14 days & 21 days \\
\hline PY & $1.04^{\mathrm{Aa}} \pm 0.17$ & $1.11^{\mathrm{Aa}} \pm 0.09$ & $1.14^{\mathrm{Aa}} \pm 0.09$ & $1.16^{\mathrm{Aa}} \pm 0.10$ \\
\hline PFSY1 & $1.24^{\mathrm{Aa}} \pm 0.11$ & $1.45^{\mathrm{Aa}} \pm 0.15$ & $1.50^{\mathrm{Aa}} \pm 0.12$ & $1.62^{\mathrm{Aa}} \pm 0.09$ \\
\hline PFSY2 & $1.60^{\mathrm{Aa}} \pm 0.13$ & $3.82^{\mathrm{Bb}} \pm 0.14$ & $5.23^{\mathrm{Cb}} \pm 0.11$ & $7.49^{\mathrm{Db}} \pm 0.12$ \\
\hline MFSY1 & $1.11^{\mathrm{Aa}} \pm 0.20$ & $1.20^{\mathrm{Aa}} \pm 0.15$ & $1.33^{\mathrm{Aa}} \pm 0.17$ & $1.38^{\mathrm{Aa}} \pm 0.18$ \\
\hline MFSY2 & $1.12^{\mathrm{Aa}} \pm 0.19$ & $1.21^{\mathrm{Aa}} \pm 0.15$ & $1.32^{\mathrm{Aa}} \pm 0.17$ & $1.39^{\mathrm{Aa}} \pm 0.18$ \\
\hline MFSY3 & $1.13^{\mathrm{Aa}} \pm 0.20$ & $1.22^{\mathrm{Aa}} \pm 0.15$ & $1.33^{\mathrm{Aa}} \pm 0.17$ & $1.39^{\mathrm{Aa}} \pm 0.19$ \\
\hline MFSY4 & $1.11^{\mathrm{Aa}} \pm 1.19$ & $1.19^{\mathrm{Aa}} \pm 0.14$ & $1.31^{\mathrm{Aa}} \pm 0.16$ & $1.37^{\mathrm{Aa}} \pm 0.18$ \\
\hline
\end{tabular}

Table.6 Effect of iron fortification on astringency in yoghurt

\begin{tabular}{|c|c|c|c|c|}
\hline \multirow{2}{*}{ Treatment } & \multicolumn{5}{|c|}{ Duration } \\
\cline { 2 - 5 } & 0 day & 7 days & 14 days & 21 days \\
\hline PY & $1.30^{\mathrm{Aa}} \pm 0.06$ & $1.46^{\mathrm{Aa}} \pm 0.07$ & $1.66^{\mathrm{ABa}} \pm 0.09$ & $1.98^{\mathrm{Ba}} \pm 0.07$ \\
\hline PFSY1 & $1.50^{\mathrm{Aa}} \pm 0.09$ & $1.76^{\mathrm{Aa}} \pm 0.09$ & $2.21^{\mathrm{ABa}} \pm 0.06$ & $2.50^{\mathrm{Ba}} \pm 0.08$ \\
\hline PFSY2 & $2.60^{\mathrm{Ab}} \pm 0.06$ & $3.83^{\mathrm{Bb}} \pm 0.16$ & $5.50^{\mathrm{Cc}} \pm 0.08$ & $7.30^{\mathrm{Dc}} \pm 0.14$ \\
\hline MFSY1 & $1.30^{\mathrm{Aa}} \pm 0.12$ & $1.50^{\mathrm{ABa}} \pm 0.13$ & $1.80^{\mathrm{BCa}} \pm 0.06$ & $2.20^{\mathrm{Ca}} \pm 0.09$ \\
\hline MFSY2 & $1.41^{\mathrm{Aa}} \pm 0.09$ & $1.51^{\mathrm{Aa}} \pm 0.14$ & $1.82^{\mathrm{Ba}} \pm 0.05$ & $2.21^{\mathrm{Ca}} \pm 0.09$ \\
\hline MFSY3 & $1.42^{\mathrm{Aa}} \pm 0.09$ & $1.52^{\mathrm{Aa}} \pm 0.13$ & $1.83^{\mathrm{Ba}} \pm 0.06$ & $2.28^{\mathrm{Ca}} \pm 0.12$ \\
\hline MFSY4 & $1.30^{\mathrm{Aa}} \pm 0.14$ & $1.50^{\mathrm{ABa}} \pm 0.12$ & $1.80^{\mathrm{Ba}} \pm 0.06$ & $2.18^{\mathrm{Ca}} \pm 0.09$ \\
\hline
\end{tabular}

Thiobarbituric acid values of microencapsulated iron fortified yoghurt (absorbance at $532 \mathrm{~nm}$ )

The data indicated that oxidation process may be quicker in yoghurt samples containing unencapsulated iron than in those containing iron in encapsulated form. These findings were in accordance with the findings of Kim et al., (2003), who reported that TBA absorbance was significantly lower in encapsulated iron fortified yoghurts than the unencapsulated iron fortified yoghurts. Similarly, Jayalalitha et al., (2012) also observed that oxidation process was quicker in yoghurt samples containing unencapsulated iron than in those containing encapsulated iron. This increase in TBA values of unencapsulated iron fortified yoghurt may be due to interaction of added iron with casein resulting in iron- casein complexes and the presence of $\mathrm{O}_{2}$, acts as a pro-oxidant, resulting in accelerated lipid oxidation in yoghurt. It can be opined that microencapsulation of iron lead to reduced rate of fat oxidation and increased fat stability, which facilitated a decreased TBA value as observed in encapsulated iron fortified yoghurt.

Effect of iron fortification on viability of Lactobacillus delbrueckii ssp. bulgaricus in yoghurt $\left(\log _{10} \mathrm{cfu} / \mathrm{ml}\right)$

Statistically no significant $(\mathrm{P}>0.05)$ difference was noticed in count of Lactobacillus delbrueckii ssp. bulgaricus between control and IFY treatments on day 0 to 21 . It is also observed that there was a significant $(\mathrm{P}<0.05)$ decrease in Lactobacillus delbrueckii ssp. bulgaricus counts as the storage period advances towards 21 days. These findings concurred with the findings of Kim et al., (2003) who reported that the mean counts of Lactobacillus delbrueckii ssp. bulgaricus for 
control and other groups of yoghurt did not differ significantly at 0 day, and also the mean counts in all groups showed a decreasing trend during 20 days of storage at $4{ }^{\circ} \mathrm{C}$. Fortification of yoghurt with different iron salts had no effect on the total lactic acid bacteria in all treatments when fresh and during cold storage El-Kholy (2011). So iron fortification did not significantly $(\mathrm{P}>0.05)$ affect the growth and viability of Lactobacillus delbrueckiis sp. bulgaricus both in the fresh yoghurt and during storage. The metabolic enzymatic activity of the yoghurt starter culture could be the reason for increase in the acidity and decrease in the $\mathrm{pH}$, which could be responsible for decreasing the viability of Lactobacillus delbrueckii ssp. bulgaricus as the storage period advances beyond a certain period.

\section{Effect of iron fortification on Streptococcus salivarius ssp. thermophilus viability in yoghurt $\left(\log _{10} \mathrm{cfu} / \mathrm{ml}\right)$}

Statistically no significant $(\mathrm{P}>0.05)$ difference was noticed in count of Streptococcus salivarius ssp. thermophilus between control and IFY treatments. Streptococcus salivarius ssp. thermophilus counts were decreased significantly $(\mathrm{P}<0.05)$ as the storage period increased among control and IFY.

These findings were in consistent with the findings of Kim et al., (2003) who reported that mean counts of Streptococcus salivarius ssp. thermophilus for control and other groups of yoghurt were not significantly different. Similarly, Cavallini and Rossi (2009) reported that viability of mixed starter culture containing Streptococcus salivarius ssp. thermophilus and Lactobacillus delbrueckii ssp. bulgaricus decreased as the storage time increased in iron and calcium fortified soy yoghurt. The reduction of Streptococcus salivarius ssp. thermophilus counts on storage may be due to low $\mathrm{pH}$ and high acidic condition prevailing in the yoghurt beyond a certain period during storage.

Effect of iron fortification on bitterness, metallic flavour and astringent flavour in yoghurt

The bitterness values and metallic flavour values of encapsulated iron fortified yoghurt were similar to control, and the bitterness values and metallic flavour values were not significantly $(\mathrm{P}>0.05)$ increased during storage periods between control and encapsulated iron fortified yoghurt. These results were partly in accordance with the findings of Kwak et al., (2003). The astringent flavour values of encapsulated iron fortified yoghurt treatment MFSY3 and unencapsulated iron fortified yoghurt treatment MFSY1 were also similar to control. These astringent flavour values were significantly $\quad(\mathrm{P}<0.05) \quad$ increased during storage periods. These results were partly in agreement with the findings of Kwak et al., (2003).

\section{Effect of iron fortification on oxidative flavour in yoghurt}

The oxidized flavour values of encapsulated iron fortified yoghurt treatment MFSY3 and unencapsulated iron fortified yoghurt treatment MFSY1 were similar to control. These oxidized flavour values were significantly $(\mathrm{P}<0.05) \quad$ increased during storage between control and Iron Fortified Yoghurt treatments. Gaucheron (2000) reported that microencapsulation techniques can be used to avoid oxidized, metallic flavours and colour changes during fortification with iron. This is supported by the findings of Jayalalitha et al., (2012), who concluded that encapsulation treatment for iron will give the good sensory quality by avoiding the oxidized flavour in iron fortified yoghurt. 


\section{Effect of iron fortification on overall preference of yoghurt}

On sensory evaluation, all the panelists preferred control yoghurt and MFSY3 over other treatments and in that order of preference. This indicated that iron can be fortified only up to $20 \mathrm{mg}$ per litre in unencapsulated form, while in the form of microencapsulated iron it can be incorporated up to $80 \mathrm{mg}$ per litre of yoghurt using ferrous sulfate without affecting the accepted appearance, sensorial and textural attributes of yoghurt.

Upon evaluation of the prepared yoghurt, it is concluded that that microencapsulated whey protein chelated iron can be incorporated up to a level of $80 \mathrm{mg}$ per litre of yoghurt without affecting the accepted appearance and taste and the viability of probiotic yoghurt bacteria, which will definitely contribute in alleviating issues related to iron deficiency.

\section{References}

Azzam, M.A., 2009. Effect of fortification with iron -whey protein complex on quality of yoghurt. Egypt. J. Dairy. Sci., 37:55-63.

Bender, D.A., and Bender, A.E.1997. "Nutrition a Reference Handbook", Oxford Univ. Press, pp: 394.

Boccio, J.R., Zubillaga, M.B., Caro, R.A., Lysionek, A., Gotelli, C.A., Gotelli, M.J., and Weill, R.1998. Bioavailability, absorption, mechanism and toxicity of microencapsulated iron (I)sulfate. Biol. Trace Elem. Res., 62:6573.

Cavallini, D.C.U., and Rossi, E.A.2009. Soy yoghurt fortified with iron and calcium: stability during the storage. Alim. Nutr, 20(1):7-13.

El-Kholy, A.M., Osman, M., Gouda, A., and Ghareeb, W.A.2011. Fortification of yoghurt with iron. World J. Dairy Food Sci., 6:159165.

Gaucheron, F., 2000. Iron fortification in dairy industry. Trends Food Sci. Tech., 11:403-409.

Jayalalitha, V., Balasundaram, V., Palanidorai, B., NareshKumar, C.2012. Fortification of encapsulated iron in probiotic yoghurt. Int. J. Agric., 2(2):80-84.

Joseph, M.H., 2000. Why countries and companies should invest to eliminate micronutrient malnutrition, Manila, Forum: International Life Sciences Institute and Micronutrient Initiative, p. 32-41.

Juneja, L.R., Sakaguchi, N, Yamaguchi, R, Nanbu, H. 2004. Iron Fortification of Dairy Products: A Novel approach, In Handbook of Functional Dairy Products," Ed. C. shortt and J.O. 'Brrien, CRC Press, London.

Kim, S.J., Ahn, J., and Kwak, H.S.2003. Microencapsulated iron for drink yoghurt fortification. Asian Australian J. Anim. Sci., 16:581-587.

Kwak, H.S., Yang, K.M., and Ahn, J. 2003. Microencapsulated iron for milk fortification. J. Agric. Food. Chem., 51(26):7770-7774.

Snedecor, G.W., Cochran, W.G. 1994. Statistical methods. Eighth edition, IOWA State University Press, USA.

Tripathi, B., and Platel, K. 2011. Iron fortification of finger millet (Eleucine coracana) flour with EDTA and folic acid as co-fortificants. Food Chem., 126, 537-542.

WHO, 2001. World Health Organisation. Iron deficiency anemia: assessment, prevention and control. A guide for programme managers, Geneva.

\section{How to cite this article:}

Elango, A., R. Subash, K.A. Doraisamy and Karthikeyan, N. 2017. Culture Viability, TBA Values and Sensorial Attributes of Yoghurt Fortified with Microencapsulated Whey ProteinChelated Iron. Int.J.Curr.Microbiol.App.Sci. 6(10): 1619-1626.

doi: https://doi.org/10.20546/ijcmas.2017.610.194 